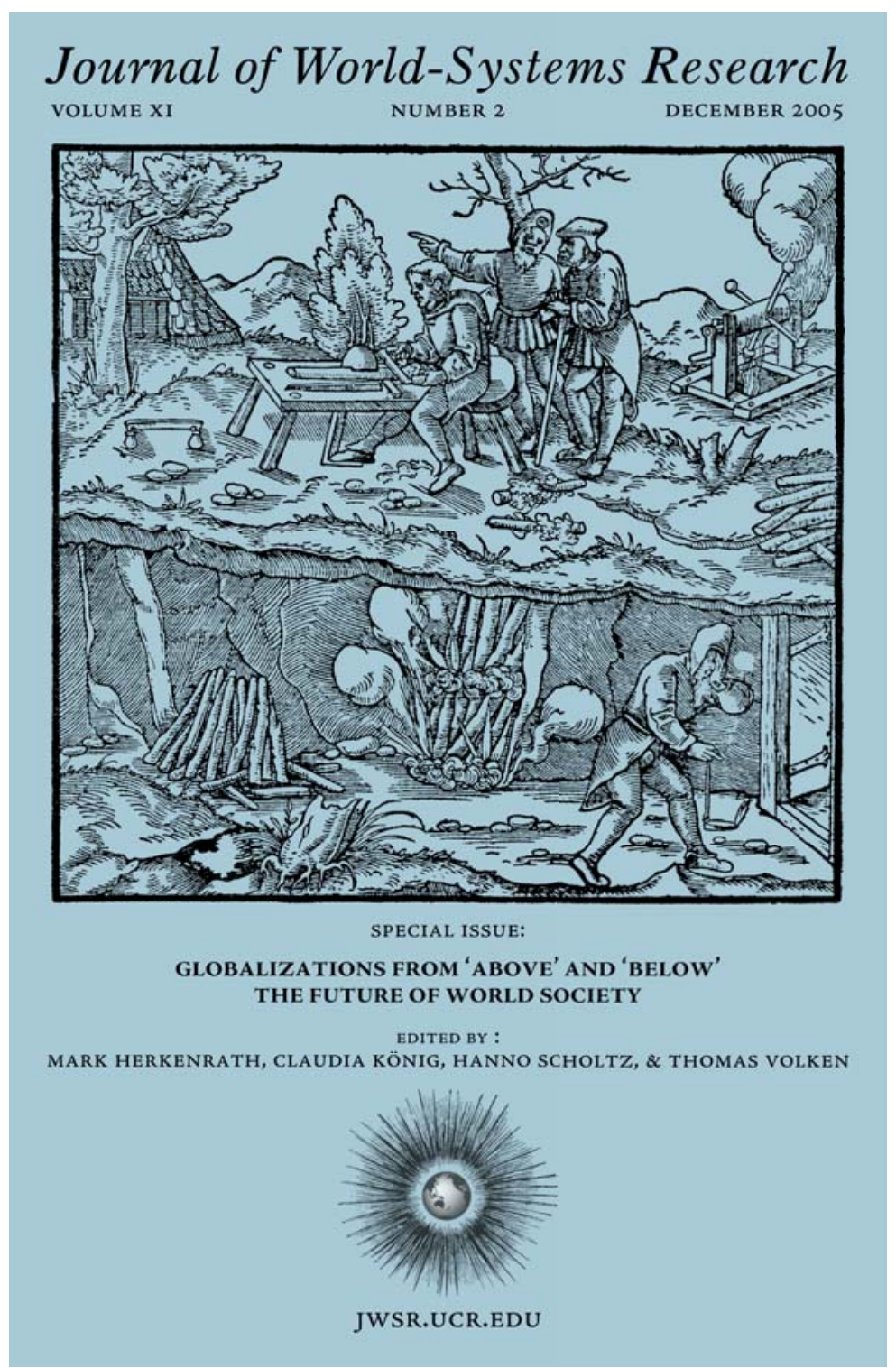

ABSTRACT:

In the paper, I first argue that we live in a fundamentally interconnected global order, integrated by complex patterns of exchange, hierarchy and solidarity among multiple glob al actors-which are increasingly aware of their interdependence and common fate. However, a universal world society does not exist yet. I then discuss the role played by international of global governance.

\section{From World System to World Society?}

Alberto Martinelli

\section{A WORLD SYSTEM}

The key question of this article is whether the contemporary world system is leading to a world society. I argue that we live in a world system as a growingly interconnected global order, but that a universal global society-as a network of social relations with mutual expectations plus a normative consensus reflected in commonly accepted institutions - does not exist yet. The contemporary world is still a system made of societies and nation states. A world society cannot be just equated with a world system. What is emerging, though among powerful counter-forces, is a global society as a world association of peoples, nation states, supranational unions, international organizations and transnational communities, who share a few core values of a cosmopolitan ethics and are integrated and regulated by a polyarchic form of democratic global governance.

We live in an increasingly interdependent world. This is the meaning I give here to the concept of world system, without entering into the different meanings that this concept has acquired in a long lasting and vast intellectual debate. The vast literature on the many dimensions of globalization provides sufficient theoretical arguments and empirical evidence for conceptualizing the entire world as a single system, although the degree and the quality of interdependence vary according to the different dimensions of globalization (it is much greater in the economic, technological and social spheres than in the cultural and political ones). Skeptics of various schools do not usually deny the existence of global flows of interdependence, although they often prefer to speak in terms of regional eco-

Alberto Martinelli

Università degli Studi di Milano

Dipartimento Studi Sociali e Politici

Facoltà di Scienze Politiche

Via Passione 13

20122 Milano, Italy

alberto.martinelli@unimi.it

http://www.unimi.it/chiedove/dipartim.idc? codice $=1284 \& \operatorname{codfac}=4$

ganizations and epistemic communities in shaping a transnational civil society and an international public space. And finally I evaluate the main factors either favoring or hindering the institutions and values of a system
JOURNAL OF WORLD-SYSTEMS RESEARCH, XI, 2, DECEMBER 2005, 24I-260 Special Issue: Globalizations from 'Above' and 'Below': The Future of World Society bttp://jwsr.ucr.edu/

ISSN I076-I56x

(c) 2005 Alberto Martinell 
nomic blocs; but they deny the presumed novelty of the phenomenon (Hirst and Thompson 1996). They tend to under-estimate what is new in contemporary globalization because they pay attention only to the economic and financial sphere.

However, whereas it is true that the world can already be considered as a single economic system in the making since the sixteenth century, contemporary globalization shows several new, distinctive features. Global interdependence has intensified and accelerated through the growing use of information and communication technologies (Castells 1996). We live in a growingly interconnected global order integrated by complex patterns of exchange, hierarchy and solidarity among multiple global actors, who show greater capacities to act in more complex networks (Martinelli 2003). The culture of globalism is also growing, i.e. the cultural attitude according to which more and more people have become aware of living in the same world, and belonging to a community of fate, mostly by virtue of the global media. This awareness can be conceptualized in various ways: we can conceive of the planet earth as an ecosystem which constitutes the common heritage of all living beings; humanity as an endangered species, with related concern for the lives of future generations; the peoples of the world as a single constituency of individuals entitled with equal rights and responsibilities, and to whom decision-makers must be accountable; the world market as an economic space regulated by an international lex mercatoria based on contracts that can guarantee not only investors' rights, but also workers', consumers', and communities' rights.

Growing interdependence and interconnectedness among peoples and states are shown by a variety of indicators, which range from the number and types of treaties to international governmental institutions, from imports and exports to levels of investments, from electronic communications traffic to measures of the ethnic, religious and linguistic composition of national populations, and from military alliances to environmental risks.

The spatial organization of social relations is deeply transformed insofar as relations become more stretched and more intensively interconnected. Transcontinental and trans-regional flows and networks of activities, exchanges and power relations are generated, with major implications for decision-making processes. New patterns of hierarchy and inequality and of inclusion and exclusion cut across national borders (Hurrel and Woods 1999). And new problems of social integration, global governance and democratic accountability arise, insofar as the sovereign power of nation states is eroded and their role in world politics is reshaped. Globalization does not proceed in a linear and uniform fashion, but with accelerations and slow-downs, in unequal ways in various parts of the world, more rapidly in certain aspects with respect to others; it sparks very different responses from institutions and individual and collective subjects; it pro- vokes opposing reactions, like for example the rediscovery of local roots and the strengthening of ethnic and regional identities (Held and McGrew 2002).

Global interdependence does not signify a reduction of the international division of labor among units that perform various functions, or of the hierarchic ordering of interdependent entities in the world system. On the contrary: even if globalization removes or weakens some access barriers to financial and commercial markets, to information and knowledge, and provokes a certain degree of power and influence redistribution, it requires strategic centers of coordination and control-national governments and transnational corporations, as well as global cities and international organizations. Fueling processes of growing differentiation and specialization, globalization creates, in fact, new complex problems of systemic integration.

Modernity has become a global condition spreading all over the world (although allowing multiple modernities, i.e. different paths toward and through modernity). Globalization expresses the radicalization of the specific dynamics of modernization (Giddens 1990): the interdependence and intensification of relations on a worldwide scale, so that locally-occurring events are shaped by distant events and vice versa; spatial-temporal distanciation, in the sense that social relations do not necessarily depend any longer on the simultaneous physical presence of actors in a specific place; the uprooting of social relations from specific contexts of interaction and their reorganization in time and space through symbolic, universal means of trade and abstract systems of scientific-technical knowledge; and the reflexivity of individuals and social systems. In other words, global interdependence implies changing experience of time and space, where time is employed to reduce constraints of space and vice versa. Time shortens and space shrinks. Yet one should not draw the (false) conclusion that different locations have become interchangeable or even less comparable, from the (true) fact of the compression of time and space, and even the annulling of the distances made possible by data communication. As Sassen (1991) effectively argues, in the current age the organization of economic activities is spread out territorially but integrated on a global level. Exactly from territorial dispersion emerges the need for a centralization of functions of control and management in the socalled "global cities" (or better "globalized cities") like New York, London, Tokyo, Shanghai.

These metropolises are at the same time decision-making and control centers of the world economy, privileged headquarters of financial firms and service sector companies, markets for the buying and selling of innovative products; they are multi-ethnic and multi-cultural. They provide a first possible clue to what a world society is, since they are the concentrated image (microcosm) and the constituent units of a world society in the making. 
Conceptualizing the world as a single system and recognizing the greater complexity of world-wide social networks, the global scope of actors' strategies, and the cosmopolitan character of global cities do not imply, however, that a world society already exists. The creation of one world, that is, the notion that the world is becoming more closely linked and integrated by common forces and practices, is a necessary condition for the emergence of a world society, but it is not a sufficient condition.

A world society cannot be equated to a world system. The world system is still a system of societies and cultures. And the world polity is still a system of nation states.

\section{DIFFERENT CONCEPTIONS OF A WORLD SOCIETY}

The existence of a world system as an interdependent whole does not necessarily imply that a world society exists. The contemporary world is still a system made of societies. But is there a world society in the making? The question whether a world society is in the making is much more controversial than the question of the world as an interconnected system, and it clearly requires a more detailed discussion. The answer depends on how we define society (a rather ambiguous concept in the language of social sciences) in general, and on what this concept means at the world level.

The history of the concept of society is a rather complex one, from its etymological root, the Latin word societas (a group of individuals who voluntarily join forces to pursue goals that they are unable to achieve singularly) to the seventeenth century English philosophers' conception of society as an artificial negotiated order, to Hegel's relation between civil society and the state, to Weber's and Toennies' pair of Gemeinschaft and Gesellschaft and contemporary sociology's pair of structure and agency. This theoretical complexity reflects itself in - and is even increased by - the conceptualization of a world society.

Some scholars simply equate world society with trans-national civil society. The classical definition of civil society stems from the crucial theoretical innovation of Scottish moralists (Smith, Ferguson, Millar) who conceptualized society as at least potentially self-organizing rather than organized by rulers. Hegel defined the bürgerliche Gesellschaft as "the conquest of the modern age" and treated it as a field in which the universal and the particular contended, to be reconciled by the state. Marx saw in it "the theatre of history," where class conflict took place. Liberal theory and republican thought developed the link between civil society and the public sphere. What all the different definitions have in common is the conceptualization of civil society as the complex of institutions and the web of social relations that organize social life at a level between the family and the state.
Contemporary social theory has maintained this core definition, either stressing specific aspects or adding new ones. Thus, civil society has been variously defined as the public sphere of civic activism, i.e. an institutional setting distinguished by openness in communication, the public use of rational critical thinking and a focus on the public good rather than simply compromises among private interests (Habermas 1985); and as the arena of non-governmental organizations, collective protest movements, and dissident associations of various kind, which played a key role in the defeat of authoritarian regimes in Eastern Europe (Kaldor 2003).

The scope of civil society has become transnational and is becoming global. At the world level, a civil society is taking shape, formed by the array of transnational communities, international non-governmental organizations, collective global movements, thematic networks, international scientific and professional associations, through which individuals negotiate social contracts and political bargains at the global level. They are significant actors in the global arena, where they interact with states and international organizations, and can play a significant role in the formation of a future world society and be a necessary requirement of democratic global governance, fostering an international public space, widely shared values and a growing awareness of our common fate as human beings. It can be empirically ascertained that the number of actors and the degree of their activism are both growing at the world level.

Civic-minded components do not exhaust, however, the forms of organized social life between the family and the state at the transnational level. Multinational corporations, religious communities, cosmopolitan elites, ethnic diasporas are also part of it and some of them are not pursuing cosmopolitan projects of peaceful co-existence, social justice, human rights or democratic governance, but religious fundamentalism, political domination, economic exploitation. Transnational civil society is conflict-ridden as much as-and even more than-its counterpart at the nation state level, because at the world level there are weaker institutional and normative requirements for the non-violent resolution of conflict. Most sociologists tend to think that the actors of civil society are good by definition, since they control state power and resist exploitation and domination. Actually, the picture is much more controversial: not only civicminded groups, but also religious and nationalist movements, are active between and beyond the control of states and families, not to speak of terrorist groups and international mafias, which are also very active in the global arena. But even if we adopt a notion of transnational civil society which is limited to civic-minded groups committed to the development of a global democratic public space, we cannot draw from its growth-which is real-the conclusion that a universal 
world society exists, since it is only a component or a dimension of a world society in the making.

Some other scholars conceptualize world society as the trans-nationalization of social classes, identifying a world bourgeoisie, a world working class, a world peasantry, etc., each with its own forms of political representation in transnational organizations and collective movements. But this is not a satisfactory conceptualization either, since the "global" classes are too heterogeneous and fragmented, lacking shared identities and common strategies, not to speak of "class consciousness." A class is a social group, the members of which share common interests - related to their position in the division of labor-distinctive cultural attitudes, preferences and lifestyles (Bourdieu 1979) and can be politically mobilized to pursue specific interests and policy objectives. The empirical evidence available does not support the existence of clearly identifiable classes at the world level, neither for workers nor for entrepreneurs and managers. Instead of a transnational working class we witness a variety of national, local and sectoral working classes, with conflicting interests, competing for jobs and with great differences in terms of wages, working conditions and social security. Although international unions exist, their action is limited by the type and stage of economic development and modernization, national legislation, patterns of labor market conditions, divisive corporate strategies; even the effort to set at least minimal standard of work safety runs into serious obstacles. Capital can organize and cooperate across national borders much more easily and efficiently than labor. Entrepreneurs and managers share a general interest in the maintenance of the capitalist market economy; the academic curricula and the professional experiences within firms which operate in the global market are often similar; the organizational structure and strategies of these corporations foster similar behavioral patterns and cultural attitudes, there are numerous examples of similar lifestyles, and frequent occasions of interaction. But all these factors are not enough to prove the existence of a truly transnational capitalist class, although some authors seem to think so (Sklair 20oI). Although its members share to a significant extent strategic objectives, common values and language-they are divided and fragmented along national and cultural lines and do not act as a single political actor.

Neither a world class struggle nor a world social-democratic compromise appear realistic. On the one hand, the national, ethnic, religious, and cultural divisions among the oppressed prevent the formation of a united revolutionary movement. On the other hand, there is no world polity where political conflict can be generalized and political demands can be transformed into policy decisions, but only separated political arenas - such as international forums of inter- governmental organizations and summits of world leaders-where movements can act and make themselves heard and visible through the global media.

In other words, the present structuration of world society does not allow the repetition at the world level of the virtuous circle of democratization which took place within the context of the democratic nation state. In the historical experience of modern democracies, markets, governments and communities closely interacted and contributed both to democratic governance and social cohesion. Sovereign states were able to tame and regulate the inherent vitality and tumultuous course of capitalist growth through regulative and redistributive policies. In the contemporary global world there is no equivalent of the nation state at the world level that could implement fiscal and welfare policies, anti-trust controls, labor and environmental laws aimed at regulating markets and at correcting market failures. Nor is there a world independent judiciary which can control and sanction illegal behavior. Nor is there a democratic polity at the world level, in which exploited and disadvantages social groups could exchange their loyalty to democratic institutions for equal rights and of legal, political and social citizenship, and could make their voices heard through their votes for decisionmakers competing for political support.

A further conceptualization of world society is that of the advocates of cosmopolitan democracy: a universal global society held together by an arching legal framework of cosmopolitan law and authority and a set of cosmopolitan institutions which disconnect legitimate political authority from its traditional anchor in fixed territories (Held 2002).

This conceptualization of the world society is the most rigorous and demanding, since it is based on a definition of society as a de facto network of social relations with mutual expectations, which requires a de jure normative consensus - that is reflected in commonly accepted institutions.

If we adopt this more rigorous definition of society we must acknowledge that at the beginning of the twenty-first century a world society as a universal global society does not exist and is not likely to exist in a foreseeable future. And yet, shared values and common institutions are gaining ground within a growing part of the world population. In fact, we live both in a single system and in a fragmented world. Globalization is marked by the tension between global economic and technological interdependence and social interconnectedness, on one hand, and cultural fragmentation and political division, on the other hand. Global cultural trends-from rationalized science and technology to the culture of human rights - co-exist with local cultures and various forms of cultural hybridization; the sentiment of a common human identity and some notion of world citizenship are still overwhelmed by national local, ethnic, religious separated and sometimes idiosyncratic identities. 
Global modernization as the spread of a global modern condition continues, but it takes the form of multiple modernities, i.e. of different paths toward and through modernity in countries marked by different cultures and civilizations (Daedalus 2000). In other words, the common problems of industrialization, urbanization, social mobilization, cultural change receive culturally different responses by different modernizing countries according to the specific genetic code of a given people and to the specific historical phase where the process takes place (Martinelli 2005). The scenario depicted by Huntington (1996) of a clash of civilizations cannot be ruled out, although it looks less likely than the alternative scenario of peaceful coexistence and positive cross-cultural fertilization. In both cases one must acknowledge a continuing and even growing cultural diversity, distinctiveness and difference, which the homogenizing trends in world culture do not reduce but actually foster and legitimize.

Given this great cultural diversity, as far as normative consensus is concerned, a world society cannot but be pluralistic. The normative order cannot be interpreted as a single coherent and idiosyncratic Weltanschauung. A world society cannot be conceptualized as a universal global society, as the projection at the world level of the modern national societies we still live in, or as the final stage in the familiar sequence of growing complexity "clan, tribe, city, state," but as an association of communities founded on the rule of law and commonly accepted norms and institutions and united in a global project of mutual respect and peaceful cooperation.

Skeptics argue that this type of normative consensus and institutional cement cannot be achieved even on a limited scale, since any sense of common identity and solidarity actually requires the existence of others with whom one does not identify, a basic distinction between them and us. In spite of the human rights charters, actually, basic rights are often violated and strategies for pursuing goals coherent with the core values of universalism are often inadequate or even utterly opposed by powerful actors on the global scene.

Other scholars add that it is not even a desirable outcome. They argue that a more realistic portrait of the world today is as an association of communities founded on the rule of law but not united in any global project (Brown 1995), or in other words, "an international society as a practical association" (Nardin 1983).

These critics are correct in pointing out the risk that global projects tend to be dominated by some powerful actor. The full accomplishment of a world society, actually runs the risk of generalizing to the whole world the ideological blueprint put forward by the political and military might of a superpower-international communism with the former Soviet Union in the recent past, or Washington consensus at the present.
But, if a society is a cooperative venture for mutual advantage (Rawls 197I), we should expect and welcome the emergence of a worldwide sense of community now that this cooperative venture is becoming worldwide in scope.

A more realistic and less risky conceptualization of world society than that of a universal global society is a world association of peoples, nation states, international organizations, supranational unions and transnational communities, integrated and regulated by a polyarchic form of global governance. This more realistic version of a world society, which is made possible by systemic interdependence and cannot but be pluralistic, requires some degree of normative consensus and commonly accepted institutions at the world level, in order to prevent that internal conflicts are not too disruptive and that a reasonable amount of trust exists among the "citizens of the world." But which are these basic normative and institutional requirements? Are they present at the world level? Which are the factors favoring and opposing them? The picture is a mixed one.

\section{COSMOPOLITAN ETHICS AND TRANSNATIONAL CIVIL SOCIETY}

Starting with the factors favoring this conception of world society, we can argue very synthetically-given the scope of this article-that a cosmopolitan ethics is emerging among significant minorities in the contemporary world, which:

- is constructed upon a basic set of common goals-peace, human dignity, social justice, individual freedom, cultural pluralism, sustainable development-but at the same time allow for multiple projects to be pursued, multiple identities and multiple citizenships;

- stems from a growing awareness of a common fate, i.e., of our common human and social rights, our common interests, our common vulnerability to global environmental, social, and political crises-such as poverty and unemployment, disease and pollution, terrorism and ethnic cleansingand the ensuing need to find common solutions and responses based on a culture of dialogue and cooperation;

- grows upon a worldwide sense of community that can be specified in terms of four basic types of consciousness: the anthropological consciousness that recognizes unity in our diversity, the ecological consciousness that recognizes our singular human nature within the biosphere, the civic consciousness of our common responsibilities and solidarity, and the dialogical consciousness that refers both to the critical mind and to the need for mutual understanding (Morin 1999); 
- fosters a cultural attitude of contextual universalism, i.e., the fertile and non-destructive encounter of cultures and the according of mutual respect among different cultural outlooks, along the lines developed by authors like Robertson (1992) and Beck (1997);

- and goes together with the diffusion of the notion of multiple citizenship through which different overlapping identities (local, national, regional, and cosmopolitan) can define different sets of rights and responsibilities; this notion does not imply that an emerging world community would require of its members an implausibly high level of cosmopolitan loyalty, overriding all other obligations to fellow nationals and those nearest to us; but it does imply a sense of common identity through which we should not be indifferent to the suffering of others, but rather give the interests of others equal weight with our own or with those of our loved ones (Nagel 1986).

These trends toward a cosmopolitan ethics find a breeding ground in several components of the transnational civil society that I discussed earlier-such as international non-governmental organizations, global collective movements, transnational epistemic communities, and cosmopolitan elites-and in the emerging transnational public space, which play a significant role in the formation of a possible future world society and which are necessary requirements of a democratic global governance.

In the transnational civil society and public space all women and men can learn to respect and try to understand others' values and beliefs without renouncing their own, but rather critically assessing and "reinventing" them in a dialogue among civilizations; this intercultural dialogue requires two basic methodological assumptions:

- the weakening of the link between ethos and ethnos, between a given vision of the world and practical knowledge, on the one hand, and the belonging to a specific community of fate, on the other; and

- the spread of self-reflexive action and thought (although rooted in a specific culture with its norms, institutions and practices, more individuals today have more chances to be responsible actors in the making of social reality).

\section{THE INSTITUTIONS OF A DEMOCRATIC WORLD SOCIETY}

These trends, which are growing albeit very unevenly, can in turn reinforce existing processes and foster new institutional processes which constitute basic building blocs of polyarchic global governance in a democratic world society such as:
- the harmonization of national laws in matters regulated by international agreements or resulting from court decisions taken in a different country;

- the strengthening of supranational institutions of governance at the world level (through a transformed United Nations Organization) and at the regional level (through a reformed European Union and similar political entities in the other regions of the world); these institutions must obtain greater authority, resources, and independence through the voluntary giving up of portions of sovereignty, in order to avoid the political chaos that the unbundling of the relationships between sovereignty, state power, and territoriality may otherwise bring about;

- the diffusion of modes of solutions to specific problems obtained through international regimes, and suggested by thematic networks and by the definition of international standards of good practices;

- the specification of rules of coexistence that are coherent with shared principles (starting with the UN declarations of universal human rights), and of procedures for making decision making processes with global implications accountable;

- the articulation of a cooperative ethos based on principles of transparency and accountability and the practice of periodical consultations with all actors involved in and affected by decisions with global implications;

- the development of self-governing communities as alternative mechanisms of social and political organization at the world level, which will foster the empowerment of individuals and groups;

- and, last but not least, the spread and consolidation of regional supranational unions like the European Union, with mechanisms of reinforced cooperation in public policy and the pooling of resources for common goals through the voluntary giving up of some sovereignty by member nation states.

\section{FACTORS HINDERING THE GROWTH OF THE CULTURE AND} INSTITUTIONS OF A DEMOCRATIC WORLD SOCIETY

The growth of a cosmopolitan ethics, the spreading of multiple citizenships, the reform of international institutions, the spread and consolidation of regional supranational unions, various forms of global collective action leading to more accountability of global decision-makers can all contribute to the growth of a democratic world society with polyarchic global governance. However, in the contemporary world there are also several political and cultural trends which act 
as powerful obstacles and counter-forces. I summarize here what I consider to be the most important ones.

First, most powerful actors on the world stage usually address matters of common concern in terms of their idiosyncratic Weltanschauungen and of their own specific goals and interests, i.e., the interests of what they consider to be their constituencies. The defense of narrowly defined national interests by state powers, the pursuing at all costs of profits and capital gains by transnational corporations and international investors, the diffusion of dogmatic beliefs by fundamentalist movements, the defense of bureaucratic privileges by inter-state organizations - all are obstacles to international cooperation and contribute to the consolidation of old inequalities and hierarchies, the fostering of new ones, and the violation of basic human rights and criteria of social justice.

Second, the strategies, decisions and actual behavior of international organizations-which by definition should have global constituencies-besides defending their bureaucratic survival and privileges, are often weighted in favor of their most powerful members (such as the Security Council members in the UN or the members of the G8). These first two tendencies lead to charges that global governance is a Western project designed to spread a kind of "pensée unique" of Western values, laws, and institutional arrangements, and to sustain the richest countries' primacy in world affairs and the expenses of the poorest and weakest ones.

Third, also as a consequence of these two tendencies deep inequalities persist among different countries and peoples, fostering legitimate charges of social injustice. Deprivation-both as absolute poverty below the threshold of daily survival and as lack of the capacity to exert one's own freedom of choice in order to better individual and collective life chances-represents a big obstacle to the development of democratic global governance and a breeding ground for aggressive movements and doctrines (more as a way of legitimating violence than as a recruiting ground for activists).

Fourth, the emergence of new forms of fundamentalism, aggressive nationalism, and tribalism - which construct people's identities upon primordial ties and dogmatic beliefs - inhibit the growth of democratic citizenship, both at the national and the supra-national levels. In today's world we are witnesses to numerous instances of the perversion of local identities, in terms of dogmatic closure, intolerances and prejudice, as a reaction to global trends. Fundamentalist religious faiths and dogmatic ideological beliefs deny the tension between the cultural message and the specific cultural code through which the message is spread, and pretend to monopolize the message, preaching irreducible truths. But in so doing they reduce the message's reach, tie it to a specific time and space, and make intercultural dialogue impossible. Fundamentalists and true believers live in an eschatological time in which reform projects of betterment of the present condition are devalued in favor of future palingenetic redemption.

Fifth, the declining participation in democratic politics and the reduced confidence in democratic processes and institutions in the developed countries with representative governments, as shown by many opinion polls-weaken the appeal of democracy and make it more difficult to "export" beyond national boundaries and to developing countries with authoritarian regimes. The growing popularity of neo-populist forms of consensus formation, which appeal to many "losers" in the globalization process, and the increasing reliance on technocratic elites, which appeals to many "winners," both reduce the space for democratic participation and accountability. Neo-populist trends of local closure and xenophobic fear of different peoples and cultures have found renewed life among political entrepreneurs in several western democracies, including France, Austria, Italy, and the Netherlands.

Sixth, the persistence of authoritarian regimes that repress civil rights and political liberties in many developing countries does not contribute to strengthening the voices in favor of democratic accountability at the global level. Authoritarian leaders of several developing countries reject any critique to their rule as undue foreign interference that violates national sovereignty and the expression of Western arrogance. International support for critical movements and opposition leaders are seen as cunning attempts to impose a neo-colonial hegemony through the weakening of their governments. Authoritarian leaders often counter the "formal" rules of democracy with the "substantial" democracy of their achievements for the well-being of their peoples. In fact, division of powers, due process of law, the multi-party system and electoral competition, freedom of speech and free information, are not instances of Western ethnocentrism, but essential ingredients of democratic life, which can be identified in different historical and cultural traditions and which must be generalized at the world level.

\section{THE PERSISTENCE OF NATION STATES AND THE EROSION OF}

\section{NATIONAL SOVEREIGNTY}

The six factors briefly discussed are in various ways and degrees the most serious obstacles to the development of the values and institutions of a democratic world society. A further obstacle is the persistence of nation states which compete with each other for power and wealth and are shaped by idiosyncratic cultural preferences. Given the resilience of the nation state as the institutional embodiment of political authority and a basic source of collective identity, a universal global society is very unlikely, but a multipolar world regulated by a form of polyarchic global governance is possible. 
The institutional embodiment of political authority in modern society has been the nation state, i.e., an impersonal and sovereign political entity with supreme jurisdiction over a clearly delimited territory and population, claiming a monopoly of coercive power, and enjoying legitimacy as a result of its citizens' support. And it still is, in spite of the erosion of its sovereignty.

Globalization tends to erode the basis of sovereignty and autonomy of nation states, but not to the extent that it is often affirmed. Scholars of different ideological orientation-from Albrow (1996), who stresses the narrowing of choices of nation states compelled to adopt neo-liberal economic policies in order to compete in the world market, to Strange (1996), who complains that the impersonal forces of world markets are more powerful than the states, to Ohmae (1995), Reinecke (1998) and Thurow (1999) who argue that globalization implies the end of the nation state as sovereign actor in international relations-have exaggerated the demise of the nation state and should be criticized for not distinguishing among states with quite different levels of power and influence. The erosion, loss or diminution of state autonomy and sovereignty is the result of growing global interdependence and interconnectedness, and it takes a variety of forms, from the permeability of national frontiers to illegal immigrants to the threats of transnational terrorism, from the constraints set by international monetary institutions on the economic policies of national governments, from the impact of transnational corporations' strategies on workers, consumers, and entrepreneurs of the countries where they operate, from the problems of coexistence between different cultures in increasingly multiethnic societies to the difficulties faced by authoritarian regimes in filtering or altogether banning the images and information of the "global village." The shrinking effectiveness of major state functions such as the control of frontiers, the effective implementation of macroeconomic and industrial policies and of welfare and redistributive policies is also the product of a conscious giving away by states through the partial concession of sovereignty to supranational institutions like the European Union.

The erosion of national sovereignty and power is, however, uneven, since states differ very much in terms of economic, political, military and cultural power and its extent has been largely overestimated. State power is rather reconstituted and transformed, at least in the developed countries and in the most powerful developing ones. In reality, because of the multifaceted impact of globalization, nation states are undergoing a deep transformation, as their functions and powers are rearticulated and re-embedded in complex transnational, regional and local networks. Global flows stimulate a variety of adjustment strategies through national policies that require a rather active state-neither the neo-liberal minimum government or the waning state, but the "developmental" or "catalytic" state. Recent financial crises and terrorist attacks have favored new forms of state intervention. In the United States the Sarbanes-Oxley law has introduced more severe controls on business financial operations and anti-terrorist laws have set constraints on the free circulation of people and goods. The European Union has intensified its anti-monopoly controls and strengthened its action against the so called "tax heavens." In Chinese modernization state control goes hand in hand with the growing opening of the economy to world trade. Many national governments compete with each other through industrial policies aimed at creating the most favorable conditions for foreign investment (friendly corporate law and fiscal policy, good infrastructures, flexible labor force, efficient public administration, etc.), while at the same time maintaining control over basic development strategies. We can therefore agree with Rosenau (1997) that the state is not dead, but rather has been reconstructed and restructured, and with Keohane (2002) that sovereignty is less a territorially defined barrier than a resource for a politics characterized by complex transnational networks of competitive country systems and regional systems. National sovereignty is increasingly challenged by transnational forces, but nation states remain key actors in global governance for quite a long time. Most of the policies that can regulate and control market processes can be effectively implemented only at the national level. The role of the judiciary in pursuing illegal market behavior-as in the Enron, Worldcom, Parmalat cases - and the role of policy in reducing the inequality of opportunities and controlling undesirable outcomes of market processes - as in the unemployment provisions of several advanced countries-are effective only at the state level or, at most, at the UE supranational level. In this respect the nation state is still very relevant, although changing.

Whatever the quality and the extent of the erosion, reconstitution and transformation of state power can be and will evolve in the near future, it is hard to deny that nation states still provide the primary source of collective identity for most people in the world, as most value survey data show. Just to take into account the two most important of them, the World Values Survey (which in its last wave of surveys include the opinions of citizens of 80 nations) and the Eurobarometer surveys (which analyze the opinions of the European Union citizens), both show that most respondents see themselves consistently through time as citizens of their nation state rather than members of their local community or of a supranational organization or citizens of the world (World Values Survey, Eurobarometer, various years). These surveys also show that for all countries where legitimate élites and/or stable governments exist, the erosion of sovereignty by global forces is compensated by citizens' demands for a more active state role in controlling international movements, negotiating agreements in international governmental organizations, coping with social and environmental problems. In many modernizing countries globalization erodes nation states' 
sovereignty, but not to the point of preventing governments from being proactive agents of development.

The continuing strength of national identities represents the main obstacle to the formation of a universal global society, since the latter lacks universally accepted identities, values and norms and widely accepted institutions. In reality, many people and groups in the contemporary world not only define their identities in idiosyncratic ways, not only hold values that are antithetical to those of others, but seek forcibly to make others' actions conform to their own preferences. There is no world society and there is no global polity. Neither is there a unified world state with a single citizenship made of all adult individuals endowed with equal rights and duties (something similar to Kant's world republic), nor a federal Union of the states of the world, nor a unified empire where member nations are hierarchically subordinated to a centralized hegemonic authority do exist or are in sight. But a world society as an association of peoples, nation states, international organizations, supranational unions and transnational communities, integrated and regulated by a polyarchic form of global governance, is slowly emerging. Given the importance of this model-which consists of the diffusion of the values of a cosmopolitan ethics and a set of democratic institutions, which I have outlined in previous paragraphs, and in spite of the powerful obstacles, which I have also discussed above-I will conclude this article with a sketchy picture of this complex entity.

\section{THE POLYARCHIC MODEL OF GLOBAL GOVERNANCE}

The world can be conceptualized as a single system, but a universal global society does not exist yet, since there is still little normative consensus reflected in commonly accepted institutions at the world level; although there are signs that they are slowly developing. In other words, the existence of a world system as an interdependent whole does not necessarily imply that a universal global society exists. The contemporary world is still a system made of societies, marked by the fundamental contradiction between open economy and closed cultures. The nation state is still the basic unit of political organization in the world polity, although its sovereignty is eroded by global flows. There is no universal global society and there is no single world polity. But, on the other hand, the contemporary world is neither just an international anarchy nor simply an international system of sovereign nation states. It is a polyarchic, multipolar, multilayered, mixed-actor system where the anarchy of sovereign states is mitigated and controlled by a plurality of non state actors: the international governmental organizations around the United Nations system, the actors of a world civil society (non-governmental organizations, collective movements, transnational communities, ethnic diasporas) and supranational unions like the European Union and by the growth of transnational civil society and public space. The progressive democratization of this polyarchic system through democratic accountability, individual and community empowerment, multiple identities, contextual universalism and deeply reformed international institutions is the major goal to be achieved in contemporary global politics. A key role in democratic global governance can be played by the European Union, both as an active peaceful player and as a model for similar global actors in the other regions of the world.

The polyarchic model of global governance-which I outline in a recent book (Martinelli 2004) - is a model in the double sense, scientific and normative, as a creative simplification of a complex reality, and as a blueprint for a peaceful global world. It combines some of the key aspects of the various approaches to democratic governance into a model of global politics which is both desirable and realistic. It is polyarchic in the sense that power and influence are shared by a plurality of institutional actors-government organizations, market organizations, and communities - which operate according to the three basic principles of authority, exchange and solidarity and whose diverse strategies act as mechanisms of social integration and governance of the world system. It is polyarchic because it is multipolar, in the sense that the hegemonic power of the United States is counterbalanced by the role played by regional powers-both supranational unions like the European Union and nation states like China, Russia, India, Brazil-in the various regions of the world. In fact, the United States may have the power to exert leadership (although recent failures in the struggle against global terrorism cast doubt on it), but its leadership can hardly be considered as legitimate by, and accountable to, constituencies outside those of the hegemonic power and its allies. Global governance can only be multi-layered if it is to be effective, and can only be democratic in order to be accepted.

It is polyarchic because it implies a multilateral system of decision-making, where major decisions with global implications are taken within international organizations - first of all a reformed United nations system - with the participation of the most significant expression of a transnational civil society in the making. And it is polyarchic because it is multi-level in the sense that institutions, rules, regimes regulate and integrate the world system at different levels on the basis of a functional specialization and of multiple citizenships which define different and overlapping sets of rights and obligations.

The polyarchic model of global governance does not neglect the persistent centrality of nation states and the asymmetries of power and influence among them, but it tends to develop democracy both above them through the formation of supranational unions on the model of the European Union, below them through the development of local self-governing communities, and laterally through the growth of non-governmental organizations, collective movements, 
epistemic communities and the like. The nation state maintains its importance as a primary source of identity and citizenship, but within a more complex system of governance which does not grow in opposition to national sovereignty but fosters the spontaneous giving of portions of sovereignty to higher level institutions and the growth of multiple citizenship. The polyarchic model acknowledges the role of global markets and transnational economic actors, but it stresses the need for them to be accountable and regulated and controlled by effective international laws.

It recognizes the role of political movements and religious and professional communities, local self-governing, transnational diasporas, but looks for the proper conditions for them to act according to the principles of cultural pluralism and contextual universalism.

The polyarchic model puts a special emphasis on the role of supranational unions on the design of the European Union: a political entity where decisions are taken both by a body representing the governments of the member countries and regions and a body representing the peoples of the member countries and regions; and a multicultural entity where unity should be achieved through diversity, with a core of shared values (democratic institutions, basic human rights, civic responsibilities, peaceful coexistence with all people on earth, free competition) that are at the foundations of common institutions, together with the respect for different cultures, languages and heritages.

To conclude: more and more people come to live in a single world system; a transnational civil society and an international public space are growing; a global communitarian culture and a cosmopolitan ethics are gaining ground. But major counter-forces are at work; a single constituency of individuals endowed with equal rights and responsibilities and to whom decision-makers must be accountable does not exist yet. And the norms and institutions concerning the organization and the regulation of social and economic life at the world level are still inadequate for pursuing the basic goals of peace, liberty, human dignity, cultural pluralism and social justice for all. A universal global society with widely shared democratic values and institutions is not yet in sight and at best is very slowly emerging.

What is possible and desirable is a world society as a world association of peoples, nations and transnational communities, integrated and regulated by a polyarchic form of global governance. Its becoming depends on the conscious efforts of individual and collective actors. The alternative to a dystopic future of an increasingly conflict-ridden, inhuman and unjust world is the project of democratic global governance as a peaceful world with polyarchic patterns of multipolar, multilayered, mixed-actor governance, democratic accountability, individual and community empowerment, multiple identities, contextual universalism, and deeply reformed international institutions. A key role in this polyarchic system of governance can be played by the European Union, both as an active, peaceful player in international politics and as a model for similar global actors in the other regions of the world.

\section{REFERENCES}

Albrow, M. 1996. The Global Age. Cambridge: Polity Press.

Beck, U. 1997. Was ist Globalisierung? Frankfurt: Suhrkamp.

Bourdieu, P. 1979. La distinction: critique sociale du jugement. Paris: Les éditions de minuit.

Brown, C. I995. "International Political Theory and the Idea of World community." In International Relations Theory Today, edited by K. Booth and S. Smith. Cambridge: Polity Press.

Castells, M. 1996. The Rise of the Network Society. Oxford: Blackwell.

Daedalus. 2000. Multiple Modernities. Daedalus I29 (I).

Eurobarometer (EB), value surveys, various years. http://europa.eu.int/comm/public opinion/index en.htm

Giddens, A. 1990. The Consequences of Modernity. Cambridge: Polity Press.

Habermas, J. 1985. Der philosophische Diskurs der Moderne. Frankfurt: Suhrkamp.

Held, D. 2002. "Law of States, Law of People. Three Models of Sovereignty." Legal Studies 8: I-44.

Held, D., and A. McGrew, eds. 2002. Governing Globalization. Cambridge: Polity Press.

Hirst, P., and G. Thompson. 1996. Globalization in Question: The International Economy and the Possibilities of Governance. Cambridge: Polity Press.

Huntington, S. P. 1996. The Clash of Civilizations and the Remaking of World Order. Cambridge: Simon and Schuster.

Hurrel, A., and N. Woods, eds. 1999. Inequality, Globalization and World Politics. Oxford: Oxford University Press.

Kaldor, M. 2003. Global Civil Society. An Answer to War. Cambridge: Polity Press.

Keohane, R.O. 2002. Power and Governance in a Partially Globalized World. London: Routledge.

Martinelli, A. 2003, "Markets, Governments, Communities and Global Governance." International Sociology I8(4): 29I-324.

Martinelli, A. 2004. Democrazia globale. Milan: Università Bocconi editore.

Martinelli, A. 2005. Global Modernization. Rethinking the Project of Modernity. London: Sage.

Morin, E. 1999. Les sept savoirs necessaires a l'education du future. Paris: Unesco.

Nagel, T. 1986. The View from Nowhere. New York: Oxford University Press.

Nardin, T. 1983. Law, Morality, and the Relations of States. Princeton: Princeton University Press.

Ohmae, K. 1995. The End of the Nation State. New York: Free Press.

Rawls, J. I97I. A Theory of Justice. Oxford: Oxford University Press. 
Reinecke, W. H. 1998. Global Public Policy: Governing Without Government? Washington, DC: Brookings Institution.

Robertson, R. 1992. Globalization. Social Theory and Global Culture. London: Sage. Rosenau, J. N. 1997. Along the Domestic-Foreign Frontier. Cambridge: Cambridge University Press.

Sassen, S. I99I. The Global City: New York, London, Tokyo. Princeton: Princeton University Press.

Sklair, L. 200I. The Transnational Capitalist Class. Malden, MA: Blackwell.

Strange, S. 1996. The Retreat of the State: The Diffusion of Power in the World Economy. Cambridge: Cambridge University Press.

Thurow, L. C. 1999. Building Wealth: New Rules for Individuals, Companies and Nations in a Knowledge-Based Economy. New York: Harper-Collins.

World Values Survey (WVS), value surveys, various years. http://www.worldvaluessurvey.org/

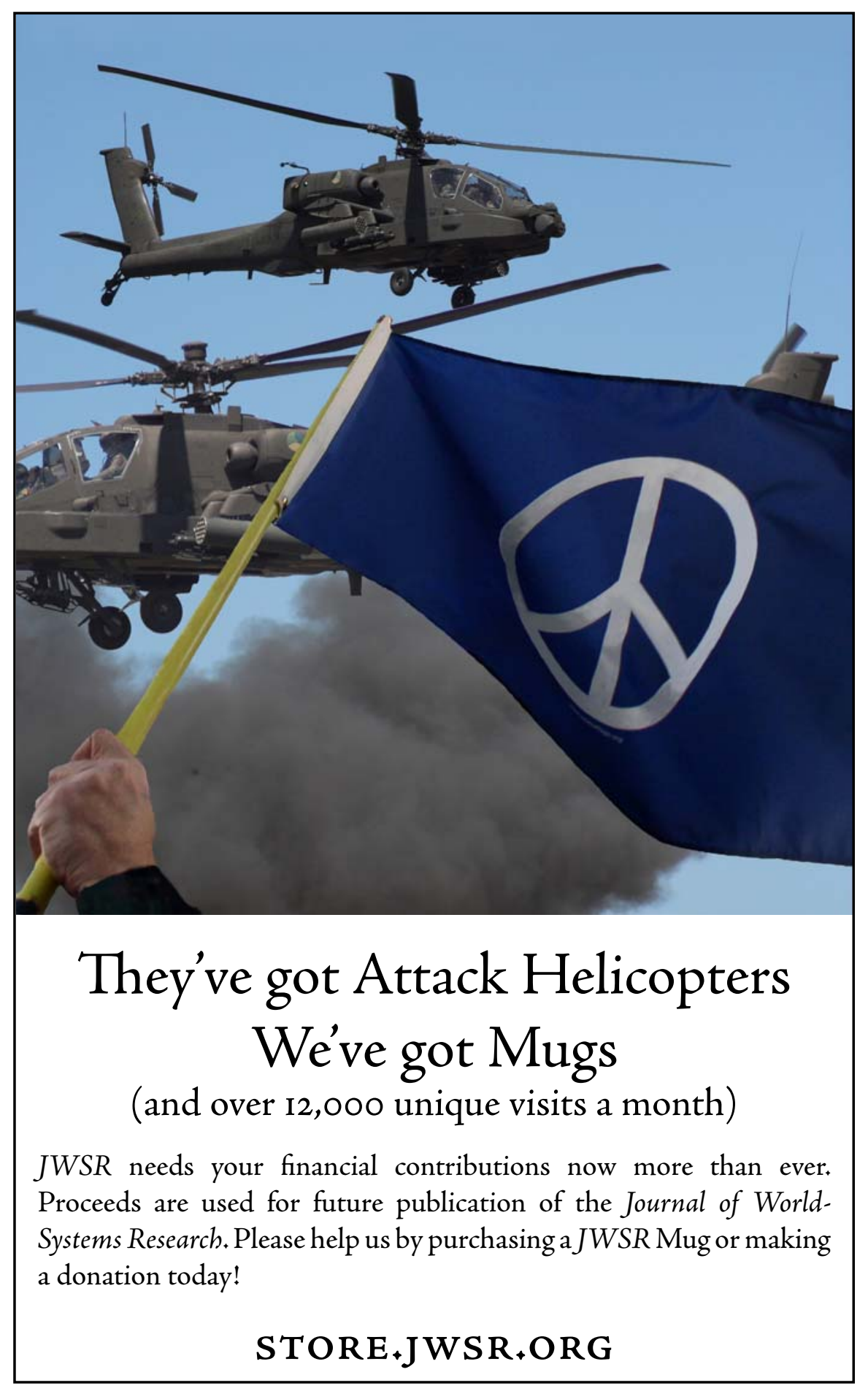

